\title{
Determinants of Big and Medium Industrial Manufacturing Agglomeration in West Java Province
}

\author{
By \\ Nur Annisa Karima*), Lilis Siti Badriah, Diah Setyorini Gunawan \\ Economic and Business Faculty, Jenderal Soedirman University \\ ${ }^{*}$ Corresponding Author: annisak248@gmail.com
}

Submission: October 8 2020, Accepted: June 212021

\begin{abstract}
The aims of this research are to analyze whether or not the manufacture industrial agglomeration in West Java Province and to analyze the factors that can affect the agglomeration especially manufacture industrial agglomeration in West Java Province. This research using Hoover Balassa Index and panel data regression with time period data 6 years (2014-2019) and 27 regencies/cities as cross-section data. The results of this research are : (1) there is no manufacture industrial agglomeration in West Java Province, (2) gross regional domestic product has a negative effect on manufacture industrial agglomeration, (3) minimum wage has a positive effect on manufacture industrial agglomeration, (4) population has a negative effect on manufacture industrial agglomeration. As an implication of the conclusion above, every province or regency/city should seek and make their region as a pole of the agglomeration and the effort that can be done are create some regulations which can support industrial establishment and development easier, giving the information about business and capital, create some regulations about wage, building partnership among companies to create backward and forward linkage.
\end{abstract}

Keywords: Agglomeration, Hoover Balassa Index, Concentration Index.

\section{ABSTRAK}

Penelitian ini merupakan penelitian dengan metode kuantitatif dan bertujuan untuk menganalisis terjadi atau tidaknya aglomerasi industri pengolahan di Provinsi Jawa Barat dan menganalisis faktor - faktor yang mempengaruhi terjadinya aglomerasi industri pengolahan besar dan sedang yang ada di Provinsi Jawa Barat. Variabel yang digunakan dalam penelitian ini adalah Produk Domestik Regional Bruto (PDRB), indeks persaingan (consentration index) dan biaya tenaga kerja. Metode analisis yang digunakan yaitu Hoover Balassa Index dan model regresi data panel dengan data periode waktu 5 tahun (2014-2018) serta 27 kabupaten/kota sebagai data cross section. Berdasarkan analisis yang dilakukan dengan aplikasi E-views dan perhitungan menggunakan Hoover Balassa Index maka hasil dari penelitian ini menunjukkan bahwa : (1) Tidak terjadi aglomerasi industri pengolahan besar dan sedang, (2) PDRB memiliki pengaruh yang positif signifikan terhadap aglomerasi industri pengolahan besar dan sedang, (3) consentration index tidak berpengaruh terhadap aglomerasi industri pengolahan besar dan sedang, (4) biaya tenaga kerja memiliki pengaruh positif signifikan terhadap aglomerasi industri pengolahan besar dan sedang. Implikasi dari hasil penelitian ini adalah setiap provinsi, kabupaten/kota harus menjadikan daerahnya menjadi pusat pertumbuhan dan membuat kebijakan yang dapat mendukung dunia bisnis dan industri, kebijakan upah, membangun kemitraan pemerintah dan swasta untuk menciptakan efek kedepan dan kebelakang.

Kata Kunci: Aglomerasi, Indeks Hoover Balassa, Indeks Persaingan. 


\section{INTRODUCTION}

Economic development is long-term efforts aimed at increasing the standard of living of the nation which can be measured by the level of real income per capita. It can be said that the goal of economic growth is to increase real national income and increase state productivity. The level of output is determined by the presence and use of natural resources, human resources, technology, market conditions, and the economic system (Suparmoko, 2002). Development in the industrial sector is part of the long-term national development plan considering that the industrial sector can make a large contribution to Gross Domestic Product (GDP). At present, the development of the industrial sector is almost always given higher priority in the development plans of developing countries. This is not without reason but because the industrial sector is considered one of the leading sectors that can drive growth and development in other sectors such as agriculture and services (Arifin, 2006).

Processed data taken from BPS shows that over the past five years (2014-2018), the manufacturing sector has experienced a decline in contributing to the formation of Gross Domestic Product even though the absolute number shows an increase from 2014 to 2018. The absolute number of industrial sectors processing released by the Central Statistics Agency, an increase in the contribution to the manufacturing sector could be one of the things behind the occurrence of agglomeration in an area because the company will assume that there is a fairly good market share in that region if it establishes a company in the region, in addition, Gross Domestic Product can be used as an indicator of the competitiveness of the industrial sector in a region (Puspita, 2016).

The problem of developing industrial competitiveness can be caused by high energy costs and economic costs related to the absence of adequate road infrastructure, bureaucratic services, incomplete industrial development based on regional potential advantages are also reasons why the contribution of the industrial sector and competitiveness of the industrial sector has decreased considering the potential resources that are not evenly distributed between regions. The difference in potential different resources in each region can be the background for the movement of production factors such as capital and labor and make industrial grouping occur only in certain areas (Zuliastri, Rindayati, Asmara, 2013).

An industrial grouping in a certain area or region or spatially the concentration of industry and economic activity is often referred to as industrial agglomeration. Studies on agglomeration can explain that the spatial concentration of industrial activities or industrial grouping can occur because economic activity actors try to obtain agglomeration savings due to localization and urbanization savings by taking locations close to each other. Spatial concentration can provide economic benefits as a result of the economics of scale. Economic agglomeration also provides positive externalities, especially for production activities and which later can make a positive contribution to the economic growth of a region (Sholihah, Soedwiwahjono, Kusumastuti, 2018).

Most of the industrial distribution in Indonesia is still on the island of Java, which is around $75 \%$ and the remaining $25 \%$ is outside the island of Java. The dominance of the distribution of the number of industries on the island of Java will continue until 2025 considering that many supporting factors make the industrial sector continue to grow (Ministry of Industry, 2012). On the island of Java, especially West Java Province, the industrial sector contributes to a larger Gross Regional Domestic Product (GRDP) when compared to other regions (BPS, 2019). The following table describes the contribution of the manufacturing sector to GRDP in several provinces on the island of Java at constant prices from 2014 to 2018. 
Table 1. Contribution of the Manufacturing Sector to the Gross Regional Domestic Product Based On Provinces in Java Island 2014-2018 (in percent)

\begin{tabular}{lccccc}
\hline \multicolumn{1}{c}{ Province } & $\mathbf{2 0 1 4}$ & $\mathbf{2 0 1 5}$ & $\mathbf{2 0 1 6}$ & $\mathbf{2 0 1 7}$ & $\mathbf{2 0 1 8}$ \\
\hline West Java & 44 & 43 & 43 & 43 & 43 \\
Central Java & 35 & 35 & 35 & 35 & 34 \\
DIY & 13 & 13 & 13 & 13 & 13 \\
East Java & 29 & 30 & 29 & 29 & 30 \\
Banten & 37 & 37 & 36 & 35 & 34 \\
\hline
\end{tabular}

Source: Central Bureau of Statistic, 2019

From Table 1 above, it can be assumed that the market in West Java Province has a low level of barriers to entry so that goods and services from the industrial sector can develop and make West Java Province the region with the largest contribution to the industrial sector if compared to other regions. The low barriers to entering the industrial market can be used to see how the industrial market structure occurs in the field and can also be seen from the concentration of the industrial market in the region (Arsyad and Kusuma, 2014).

The industrial sector is also closely related to the use of inputs in the production process. One of the most important inputs in the running of the production process is labor. Workers who have carried out the production process will receive remuneration in the form of wages or compensation for their work. Labor costs (wages) based on previous empirical research state that a high wage rate will reduce the chances of spatial concentration or industrial agglomeration in an area because entrepreneurs tend to set up businesses in areas that have low wage rates (Emalia, 2017).

Based on the description above, the topic of this research is taken is "Analysis of Factors Affecting Agglomeration of Large and Medium Manufacturing Industries in West Java Province". This study aims to analyze whether large and medium processing industry agglomerations occur or not in West Java Province and the factors that influence it.

\section{METHODS}

This study uses a quantitative approach. The data used by the author is secondary data which can be obtained from various sources such as the Central Statistics Agency (BPS), journals, literature, and previous research. To analyze the spatial concentration of industry, the Hoover Balassa Index (HBI) is used. This index is a measure to determine whether an industry is agglomerated in an area or not (Sbergami, 2002) and this index can be searched using the formula:

$$
\mathrm{HBI}_{i \mathrm{t}}=\frac{S_{i t}}{X_{i t}}
$$

Where :

$\mathrm{S}_{i t}$ : Share of the industrial workforce in province $i$ to total industrial workforce of province $i$ in year $t$. $X_{i t}$ : Share of the industrial workforce in province $i$ at the national level in year $t$.

The index value> 1 indicates that the leading industry is agglomerated in a region because the share of the province's leading industry workers is greater than the share at the national level (in aggregate). Conversely, if the index value $<1$ indicates that the industry is not agglomerated (Zuliastri, Rindayati, Asmara, 2013).

The model used to analyze the factors that influence industrial agglomeration in West Java Province is panel data regression analysis model with the following equation:

$$
Y_{i t}=\beta_{0}+\beta_{1} X_{1 i t}+\beta_{2} X_{2 i t}+\beta_{3} X_{3 i t}+e_{i t}
$$


Where :

$\begin{array}{ll}Y_{\text {it }} & : \text { Agglomeration in Region } i \text { in Year } t \\ \beta 0 & : \text { Coefficient Intercep } \\ \beta 1, \beta 2, \beta 3 & : \text { Coefficient Regression } \\ \mathrm{X} 1 & : \text { GRDP Each Regency/City } \\ \mathrm{X} 2 & : \text { Market Structure (Concentration Index) in Industrial Sector } \\ \mathrm{X} 3 & : \text { Wages } \\ \mathrm{i} & : \text { Region } \\ \mathrm{t} & : \text { Year } \\ \mathrm{e} & : \text { Error Term }\end{array}$

\section{RESULTS AND DISCUSSIONS} Panel Data Estimation

The panel data used consists of 2014-2018 time-series data and data from 27 districts or cities in West Java Province. After the data is regressed using the panel data method and incorporating the Chow test, Hausman test, and Lagrangian Multiplier test, the best model used to regress panel data in this study is the random-effects model. The following shows the results of panel data regression:

Table 2. Panel Data Regression Result

\begin{tabular}{llll}
\hline Variable & Coefficient & t-Statistic & P.value \\
\hline $\mathrm{C}$ & -0.0174 & -0.6104 & 0.5427 \\
GRDP & $4.70 e-10$ & 2.354 & 0.0201 \\
$\mathrm{CI}$ & -0.000191 & -0.2359 & 0.8138 \\
WAGES & $4.62 e-08$ & 3.160 & 0.0020 \\
\hline
\end{tabular}

Source: Processed Data, 2020

\section{Classic Assumption Test}

Heteroscedasticity Test

To determine whether heteroscedasticity occurs or not, it can be seen from the Chi-Square probability value, if the probability value is greater than 0.05 , the model is free from heteroscedasticity problems. The regression results show the Chi-Square probability value of 0.2073 , which means that the model does not experience heteroscedasticity.

Multicollinearity Test

From Table 3 it can be seen that each of the independent variables used in the study does not experience multicollinearity problems because it has a variance inflation factor value of less than 10.

Table 3. Multicollinearity Test Result

\begin{tabular}{lc}
\hline Variable & VIF \\
\hline GRDP & 1.623 \\
Cl & 1.098 \\
WAGES & 1.710 \\
\hline
\end{tabular}

Source: Processed Data, 2020

\section{Autocorrelation Test}

The statistical Durbin Watson value obtained is 0.6341 which when compared to the DW value table, the model experiences positive autocorrelation. But when viewed from the model used, namely the panel data model, the autocorrelation problem is a tolerable problem or this model is immune to autocorrelation problems (Gujarati, 2009). 


\section{Normality Test}

The Jarque Bera probability value shows the number 0.000 smaller than alpha 0.05 , which means the data is not normally distributed. But because the number of observations used in this research is quite large $(n>30)$, then the assumptions of the Central Limit Theory can be used and put aside the problem of normality.

\section{Coefficient Determination}

The $R^{2}$ value is 0.2507 , which means that the proportion of the agglomeration variable $(Y)$ can be explained by the GRDP variable (X1), the concentration index (X2), and the wage variable (X3) together at 25 percent and the remaining 75 percent is explained by other variables which are not included in this research.

\section{(F-Test)}

The results of regression analysis obtained a probability of 0.0000 which indicates less than $\alpha=0.05$ and means that the independent variables (GRDP, concentration index, and wages) together have a significant effect on industrial agglomeration variables.

\section{Partial Test (t-Test)}

Based on the regression results listed in Table 2, the GDP variable and wages have a statistical t value greater than $t$ table 1.660 which means that the GRDP and wages variables have a significant positive effect on agglomeration, while the concentration index variable has a statistical $t$ value smaller than $t$ table 1.660 which means that the concentration index variable does not have a significant positive effect on agglomeration.

\section{Analysis of Big and Medium Industrial Manufacturing Agglomeration in West Java Province}

Table 4 shows the value of the Hoover Balassa Index for the last five years which has an average value of 0.0997 balassa. It shows a value smaller or less than 1 , which means that there is no industrial agglomeration in West Java Province. According to Marshall's view, which is often referred to as the Marshallian Industrial Distinct, suggests that agglomeration or spatial concentration, especially in the industrial sector, will occur if labor is available, especially a specialized workforce because this specialized workforce will be more easily employed in related industries which are concentrated in one area. Apart from having to be supported by the availability of labor, industrial agglomeration must be supported by good regional conditions and also the availability of good infrastructure, both road infrastructure, communication, and telecommunications infrastructure (Wulandari, 2019).

Table 4. Hoover Balassa Index

\begin{tabular}{cc}
\hline Year & Hoover Balassa Index Value \\
\hline 2014 & 0.0884 \\
2015 & 0.0940 \\
2016 & 0.0842 \\
2017 & 0.1178 \\
2018 & 0.1143 \\
\hline
\end{tabular}

Source: Processed Data, 2020

\section{Gross Regional Domestic Product (GRDP)}

The results of data analysis indicate that the GRDP variable has a positive effect on large and medium industrial agglomerations. The results of this analysis are in line with the hypothesis in the study (Puspita, 2016). It can be concluded that the greater the industrial sector's contribution to the formation of Gross Regional Domestic Product (PDRB), so this will indicate the emergence of agglomeration and show the availability of markets in districts/cities in West Java Province (Puspita, 
2016). The contribution of the industrial sector to the formation of GRDP will be easier to occur in areas with large market availability and generally have a population that tends to be dense. Because this will affect the level of demand and supply and encourage the emergence of new industries to meet market needs (Tilaar, 2010).

\section{Concentration Index}

The results of data analysis indicate that the concentration index variable does not affect industrial agglomeration. The calculation of the concentration index shows a value of 4.3374 . According to Glaeser, et al (1992), if the concentration index has a value greater than 1, then the industry in an area tends to be more competitive compared to other regions and has many companies running in that area. The results of the calculation of the concentration index show a number greater than 4 , which means that the market is quite competitive. However, it is indicated that the processing industry in West Java Province does not have significant externalities between industries (lack of backward and forward linkage levels), thereby reducing the opportunity for agglomeration of the processing industry in West Java Province. This still cannot be said as industrial agglomeration, but only as a spatial cluster (Winardi, et al, 2017). The insignificant concentration index probability value of 0.8138 is also in line with the Hoover Balassa Index's value of 0.0997 which indicates that large and medium industrial agglomerations are not possible in West Java Province so that there is no efficiency in terms of adjacent locations associated with spatial clusters of companies, workers, and consumers. This is different from the hypothesis presented in the study (Zuliastri, Rindayati, Asmara, 2013) which suggests that a concentrated market will promote agglomeration. The results of the analysis in this study reject the hypothesis, which means that the higher the level of market concentration or the tighter the existing market structure will slow down the occurrence of industrial agglomeration.

\section{Wages}

The results of data analysis indicate that the variable wages have a significant positive effect on the formation of industrial agglomerations. The increase in wages will have a positive effect such as allowing an increase in the level of agglomeration and also several other positive effects that have a relatively small effect. The wage variable has a positive effect because as asserted in the Efficiency Wage Theory that by providing high wages, a company will run more efficiently and profitably because giving high wages will increase productivity and prevent workers from leaving the company which can lead to new businesses to seek return workers. This statement is in line with the concept of industrial agglomeration which is said to be the saving or efficiency of economic activities as well as labor efficiency due to the concentration of labor in an area (Mankiw, 2006). The provision of high labor costs affects the occurrence of agglomeration because workers tend to choose to work in locations and/or jobs that can provide promising wages. This shows that the analysis results reject the hypothesis that wages have a negative effect on the formation of industrial agglomeration.

\section{CONCLUSIONS}

The average value of the Hoover Balassa index from 2014 to 2018 shows that there is no industrial agglomeration in West Java Province. Gross Regional Domestic Product (GRDP), concentration index, and wages together (simultaneously) affect industrial agglomeration variables in West Java Province. Meanwhile, if partially, the Gross Regional Domestic Product (GRDP) variable and the wage variable have a significant positive effect on industrial agglomeration in West Java Province. Meanwhile, the concentration index variable does not affect industrial agglomeration in West Java Province. The implication of this research is that agglomeration must be strived to occur so that it can have a multiplier effect on other aspects such as the amount of labor absorbed which in other words can reduce unemployment, encourage labor urbanization and increase knowledge spillover which is very important for the formation of human capital accumulation which absolutely will also be strengthened by learning by doing and will ultimately increase industrial output and industrial growth. The limitation in this study is that the researcher only includes the Gross Regional Domestic 
Product (GRDP), market structure (proxy by concentration index), and wages. It is expected that further research can include the use of other variables such as resource intensity, import content, path dependency or age distribution of companies, export orientation, and foreign investment. Another limitation of this study is the use of a model that is still experiencing autocorrelation, so it is expected that in future studies it can choose and use a more appropriate model to avoid autocorrelation.

\section{REFERENCES}

Arifin, Z. (2006). Spatial Concentration of Industrial Manufacturing Based on Fishery Sector on East Java. Jurnal Humanity. Volume 1. Page 142-151.

Arsyad, L., Kusuma, S, E., (2014). Ekonomika Industri. Yogyakarta : UPP STIM YKPN

Badan Pusat Statistik. (2019). Gross Regional Domestic Product by Provinces in Indonesia Based on Industrial Origin 2014-2018. Retrieved from https://www.bps.go.id/publication/2019/07/26/dc449d34a26ec840acb305a9/produk-domestik regional-bruto-provinsi-provinsi-di-indonesia-menurut-lapangan-usaha-2014-2018.html

Emalia, Z. (2017). Determinant Of Industrial Manufacturing Agglomeration in West Java Province. In: Prosiding Call Paper Dan Seminar Nasional FEB UNILA 2017. Fakultas Ekonomi dan Bisnis, pp. 145-151.

Glaeser, E. L., Kallal, H. D., Scheinkman, J. A., \& Shleifer, A. (1992). Growth in cities. Journal of Political Economy, 100(6), 1126-1152.

Gujarati, D. N. (2009). Basic Econometrics. Tata McGraw-Hill Education.

Kuncoro, M. (2002). Analisis Spasial dan Regional (studi aglomerasi dan kluster industri Indonesia). Yogyakarta : UPP AMP YKPN

Mankiw, N. G. (2003). Makroekonomi, Edisi 6. Jakarta: Penerbit Erlangga.

Kementerian Perindustrian. (2012). Pemerintah Andalkan Pertumbuhan Industri Pulau Jawa. Retrieved from https://kemenperin.go.id/artikel/2806/Pemerintah-Andalkan\%09PertumbuhanIndustri-Pulau-Jawa.

Puspita, Y. (2016). The Effect of Economy of Scale, Wage, GRDP, Labor Productivity, Proportion of Rural Areas of Small and Medium Industry Agglomeration in East Java. Jurnal Strategi dan Bisnis. Volume 3. No.2 Jember : Universitas Jember.

Sbergami, F. (2002). Agglomeration and economic growth: some puzzles (No. 02). Graduate Institute of International Studies.

Sholihah. D.A., Soedwiwahjono and Kusumastuti (2018). Impact of Industrial Agglomeration Development in Gondangrejo, Karanganyar on Spatial Change. Jurnal Pembangunan Wilayah dan Perencanaan Partisipatif. Volume 13. Page 115-132.

Suparmoko. (2002). Ekonomi Pembangunan. Yogyakarta : BPFE

Tilaar, Sony. (2010). Overview of the Distribution of Industrial Agglomeration in Indonesia. Jurnal TEKNO Universitas Sam Ratulagi. Volume 07. No. 52.

Winardi, W., Priyarsono, D. S., Siregar, H., \& Kustanto, H. (2017). Performance Manufacturing Sector in West Java Based on The Location Inside and Outside Industrial Zone. Journal of Technology Management, 16(3), 241-257.

Wulandari, Y., Lestari, E. K., \& Subagiarta, I. W. (2019). Agglomeration of Industrial Manufacturing in Jember Regency 2011-2015. e-Journal Ekonomi Bisnis dan Akuntansi, 6(1), 76-80.

Zuliastri, F., Rindayati, Wiwiek., Asmara, Alla., (2013). Analysis of Factors Affecting Leading Industry Agglomeration Regions Linked to the Regional Industrial Competitiveness. Jurnal Ekonomi dan Kebijakan Pembangunan. Volume 2. Page 2. 